\title{
Long term effect of integrated nutrient management on soil properties and availability of nutrients in a Typic Hapludalfs under maize-wheat cropping ${\text { Babita Bharti }{ }^{1^{*}} \text {, Raj Paul Sharma }}^{2}$ \\ CSK HPKV, Palampur, H.P., India
}

\begin{abstract}
To study the long term effect of integrated nutrient management on soil properties and available nutrients, surface and subsurface soil samples were drawn from the long-term field experiment (LTFE) which is in progress on a Typic Hapludalfs at Research Farm of College of Agriculture, CSK HPKV, Palampur, Himachal Pradesh, India since Rabi, 1972. The rotation followed was maize-wheat and the treatments included various combinations of $N, P, K$, $Z n$, lime, hand weeding and farm yard manure. Results from the study showed that integrated nutrient management over the years resulted in improvement in the soil properties as well as status of available nutrients in the soil at both the depths. Continuous application of urea as a source of $N$ has resulted in acidification of soils ( $\mathrm{pH} 4.3$ ) while lime application increased the $\mathrm{pH}$ to 6.2 in the surface soil and 6.0 in subsurface soil. The treatment $100 \%$ NPK + FYM resulted in 66 per cent increase in soil organic carbon content over initial value. Similar effects were recorded on cation exchange capacity and available nutrients. It can be concluded from the study that integrated nutrient management is essential to maintain soil health.
\end{abstract}

Keywords — Integrated nutrient management, soil properties, long-term effect.

\section{INTRODUCTION}

Fertilizers play vital role in productivity of any crop but continuous and imbalanced use of high analysis chemical fertilizers badly influences soil health and ultimately production potential of soil. With the advent of modern agriculture, farmers are either using restricted amount of organics or no organics. As a result of such nutrient management practices, many of the productive soils are becoming unproductive. This has led to decreasing yield trend even with optimum use of fertilizers particularly under the situations where high yielding varieties are being used. The problem is more severe in acid soils which are under intensive cropping. To secure India's food and nutritional demands, maintenance of soil health is indispensable. Chemical fertilizers alone are unable to maintain the long-term soil health and crop productivity (Subba Rao \& Srivastava 1998) as they lack in secondary and micronutrients. Continuous cropping and long-term fertilization are liable to change soil properties and crop productivity. Long-term fertilizer experiments provide the best possible base to monitor changes in soil quality and crop productivity due to continuous manuring and cropping and hence to evolve future strategies for maintaining soil health and enhancing crop yields. With this background, the long term effect of fertilizers and amendments on soil properties and available nutrients was evaluated in the present study.

\section{MATERIALS AND METHODS}

The long-term fertilizer experiment was laid out during 1972-73 (Rabi) under All India Coordinated Research Project on Long-term Fertilizer Experiment to study the effect of various combinations of N,P,K, Zn, lime, hand weeding and farm yard manure on soil quality and maize-wheat productivity. The long- term fertilizer experiment was laid out at the farm of College of Agriculture, Palampur, Himachal Pradesh $\left(32^{0} \mathrm{~N}, 76^{0} \mathrm{E}, 1280 \mathrm{~m}\right.$ above mean sea level) representing wet temperate zone of Western Himalaya. The soil of the experimental site at the start of the experiment was acidic in reaction ( $\mathrm{pH} 5.8$ ) and silt loam in texture. Taxonomically, the soils are classified as Typic Hapludalfs. The experiment initially comprised of 10 treatments each replicated four times in randomized block design (RBD). The $11^{\text {th }}$ treatment consisting of 100 per cent NPK (-S) was introduced in kharif, 1981. Treatments were, $\mathrm{T}_{1}$-control; $\mathrm{T}_{2}-100 \% \mathrm{~N} ; \mathrm{T}_{3}-100 \% \mathrm{NP} ; \mathrm{T}_{4^{-}}-100 \% \mathrm{NPK} ; \mathrm{T}_{5}-100 \% \mathrm{NPK}$ + FYM @10 t ha ${ }^{-1}$ (to maize crop only); $\mathrm{T}_{6}-100 \% \mathrm{NPK}+$ lime (lime was applied @ $900 \mathrm{~kg} \mathrm{ha}^{-1}$ till the pH attained at neutrality); $\mathrm{T}_{7}-100 \% \mathrm{NPK}+\mathrm{Zn} ; \mathrm{T}_{8}-100 \% \mathrm{NPK}+$ Hand Weeding $(\mathrm{HW}) ; \mathrm{T}_{9}-100 \% \mathrm{NPK}(-\mathrm{S}), \mathrm{P}$ through DAP; $\mathrm{T}_{10}-150 \%$ NPK (super optimal) and $\mathrm{T}_{11^{-}} 50 \%$ NPK (sub optimal). The N, P and $\mathrm{K}$ were applied through urea, single super phosphate and muriate of potash, respectively. In case of 100 per cent NPK (-S), phosphorus was applied through di-ammonium phosphate (DAP). Farm yard manure (FYM) was applied @ $10 \mathrm{t} \mathrm{ha}^{-1}$ to maize crop only in a system. Chemical weed control measures were followed except in treatment on hand weeding $(100 \%$ NPK + HW) in which the weeds were removed manually. Half the dose of $\mathrm{N}$ and full dose of $\mathrm{P}$ and $\mathrm{K}$ were applied at the time of sowing of both the crops. The remaining 
half of the $\mathrm{N}$ was top dressed in two equal splits at knee high and tasselling stage of maize and maximum tillering and flowering stage of wheat crops, respectively.

After continuous cropping for 37 years, soil samples after harvest of wheat crop (Rabi 2008-09) were drawn at 0-0.15 m and 0.15-0.30 m depths to assess soil $\mathrm{pH}$, organic carbon, cation exchange capacity, available nitrogen, available phosphorus and available potassium. Standard methods were used to determine $\mathrm{pH}$, organic carbon, cation exchange capacity, available nitrogen, available phosphorus and available potassium in the soil.

\section{RESULTS AND DISCUSSION}

\subsection{Soil pH}

A perusal of data in table 1 showed that continuous cropping and fertilization caused a reduction in soil $\mathrm{pH}$ from its initial value of 5.8 recorded in 1972 before the initiation of the experiment. Application of urea as a source of $\mathrm{N}$ over the years has resulted in acidification of soils while lime application increased the $\mathrm{pH}$ to 6.2 in the surface soil and 6.0 in subsurface soil. The soil $\mathrm{pH}$ in the sub-surface soil layer $(0.15-0.30 \mathrm{~m})$ varied from 4.3 to 6.0 and the treatment wise trend was almost similar to that in the surface layer.

TABLE 1

EFFECT OF LONG-TERM USE OF CHEMICAL FERTILIZERS AND AMENDMENTS ON SOIL PH

\begin{tabular}{|c|c|c|}
\hline \multirow{2}{*}{ Treatment } & \multicolumn{2}{|c|}{ Soil depth(m) } \\
\cline { 2 - 3 } & $\mathbf{0 - 0 . 1 5}$ & $\mathbf{0 . 1 5 - 0 . 3 0}$ \\
\hline $\mathrm{T}_{1}:$ Control & 5.5 & 5.4 \\
\hline $\mathrm{T}_{2}: 100 \% \mathrm{~N}$ & 4.3 & 5.3 \\
\hline $\mathrm{T}_{3}: 100 \% \mathrm{NP}$ & 5.1 & 5.1 \\
\hline $\mathrm{T}_{4}: 100 \% \mathrm{NPK}$ & 5.2 & 5.0 \\
\hline $\mathrm{T}_{5}: 100 \% \mathrm{NPK}+\mathrm{FYM}$ & 5.1 & 6.0 \\
\hline $\mathrm{T}_{6}: 100 \% \mathrm{NPK}+$ lime & 6.2 & 4.8 \\
\hline $\mathrm{T}_{7}: 100 \% \mathrm{NPK}+\mathrm{Zn}$ & 4.9 & 5.3 \\
\hline $\mathrm{T}_{8}: 100 \% \mathrm{NPK}+\mathrm{HW}$ & 5.0 & 4.9 \\
\hline $\mathrm{T}_{9}: 100 \% \mathrm{NPK}(-\mathrm{S})$ & 4.9 & 4.8 \\
\hline $\mathrm{T}_{10}: 150 \% \mathrm{NPK}$ & 4.8 & 5.2 \\
\hline $\mathrm{T}_{11}: 50 \% \mathrm{NPK}$ & 5.2 & - \\
\hline Initial & 5.8 & 0.23 \\
\hline $\mathrm{CD}(\mathrm{P}=0.05)$ & 0.23 & \\
\hline
\end{tabular}

HW = Hand weeding

Prasad et al. (1996) and Sharma et al. (2002) reported the moderating effect of FYM and phosphatic fertilizers on pH. This might be attributed to decrease in the activity of exchangeable $\mathrm{Al}^{3+}$ ions in the soil solution due to chelation effect of organic molecules (Hue, 1992) and formation of alumino-phosphate complexes, respectively. The marked decline in $\mathrm{pH}$ due to the application of $100 \% \mathrm{~N}$ alone could be ascribed to acidity producing nature of urea as nitrogenous fertilizer (Magdoff $e t$ al., 1997) which upon nitrification releases $\mathrm{H}^{+}$ions which are potential sources of soil acidity. The application of lime has raised the $\mathrm{pH}$ of soil to about 6.2. The ameliorating effect of lime on soil acidity has been reported by many workers (Sharma $e$ t al. 2002).

\subsection{Soil Organic Carbon}

Perusal of data in table 2 revealed that except control, the rest of the treatments had shown a slight build up in the content of soil organic carbon over the years. The treatment $100 \%$ NPK + FYM resulted in 66 per cent increase in soil organic carbon content over initial value. The soil organic carbon content in $\mathrm{T}_{8}$ was 9.2 per cent higher than $\mathrm{T}_{4}$. The organic carbon content in subsurface layer ranged from 4.8 under control to $9.8 \mathrm{~g} \mathrm{~kg}^{-1}$ under $100 \% \mathrm{NPK}+\mathrm{FYM}$ treatment. The surface soils contained higher amount of organic carbon in comparison to the subsurface soils. The pattern of effect of different treatments on soil organic carbon content was similar as that recorded in surface layer. 
TABLE 2

EFFECT OF LONG-TERM USE OF CHEMICAL FERTILIZERS AND AMENDMENTS ON SOIL ORGANIC CARBON $\left(\mathrm{g} \mathrm{kg}^{-1}\right)$

\begin{tabular}{|c|r|c|}
\hline \multirow{2}{*}{ Treatment } & \multicolumn{2}{|c|}{ Soil depth(m) } \\
\cline { 2 - 3 } & $\mathbf{0 - 0 . 1 5}$ & $\mathbf{0 . 1 5 - 0 . 3 0}$ \\
\hline $\mathrm{T}_{1}:$ Control & 8.0 & 4.8 \\
\hline $\mathrm{T}_{2}: 100 \% \mathrm{~N}$ & 9.3 & 6.3 \\
\hline $\mathrm{T}_{3}: 100 \% \mathrm{NP}$ & 9.6 & 6.0 \\
\hline $\mathrm{T}_{4}: 100 \% \mathrm{NPK}$ & 10.0 & 6.7 \\
\hline $\mathrm{T}_{5}: 100 \% \mathrm{NPK}+\mathrm{FYM}$ & 13.1 & 9.8 \\
\hline $\mathrm{T}_{6}: 100 \% \mathrm{NPK}+$ lime & 10.1 & 6.1 \\
\hline $\mathrm{T}_{7}: 100 \% \mathrm{NPK}+\mathrm{Zn}$ & 9.4 & 5.7 \\
\hline $\mathrm{T}_{8}: 100 \% \mathrm{NPK}+\mathrm{HW}$ & 11.0 & 9.0 \\
\hline $\mathrm{T}_{9}: 100 \% \mathrm{NPK}(-\mathrm{S})$ & 9.8 & 5.9 \\
\hline $\mathrm{T}_{10}: 150 \% \mathrm{NPK}$ & 10.1 & 7.2 \\
\hline $\mathrm{T}_{11}: 50 \% \mathrm{NPK}$ & 9.8 & 6.8 \\
\hline Initial & 7.9 & - \\
\hline $\mathrm{CD}(\mathrm{P}=0.05)$ & 0.29 & 0.33 \\
\hline
\end{tabular}

The substantial build up in soil organic carbon content in $100 \%$ NPK + FYM treatment was due to the added source of carbon through FYM in $\mathrm{T}_{5}$ and addition of root biomass and crop residues for thirty six years. The enhanced crop productivity and associated greater returns of organic matter in the form of decaying roots and crop residues in plots receiving balanced dose of either NPK alone or with amendments often gives rise to high organic carbon levels. Slow rate of organic matter decomposition in wet temperate zone could be another reason for buildup of soil organic carbon (Acharya $e t$ al., 1988; Sharma et al., 2002).

\subsection{Cation Exchange Capacity}

A perusal of the data revealed that the CEC in the surface layer ranged from $8.7 \mathrm{c} \mathrm{mol}\left(\mathrm{p}^{+}\right) \mathrm{kg}^{-1}$ under control to $12.3 \mathrm{c} \mathrm{mol}$ $\left(\mathrm{p}^{+}\right) \mathrm{kg}^{-1}$ under $100 \% \mathrm{NPK}+\mathrm{FYM}$ (Table 3$)$.

TABLE 3

EFFECT OF LONG-TERM USE OF CHEMICAL FERTILIZERS AND AMENDMENTS ON CATION EXCHANGE CAPACITY $\left\{\mathrm{c} \mathrm{mol}\left(\mathrm{p}^{+}\right) \mathrm{kg}^{-1}\right\}$

\begin{tabular}{|c|c|c|}
\hline \multirow{2}{*}{ Treatment } & \multicolumn{2}{|c|}{ Soil depth(m) } \\
\cline { 2 - 3 } & $\mathbf{0 - 0 . 1 5}$ & $\mathbf{0 . 1 5 - 0 . 3 0}$ \\
\hline $\mathrm{T}_{1}:$ Control & 8.7 & 7.2 \\
\hline $\mathrm{T}_{2}: 100 \% \mathrm{~N}$ & 6.8 & 7.8 \\
\hline $\mathrm{T}_{3}: 100 \% \mathrm{NP}$ & 9.5 & 9.1 \\
\hline $\mathrm{T}_{4}: 100 \% \mathrm{NPK}$ & 10.6 & 11.4 \\
\hline $\mathrm{T}_{5}: 100 \% \mathrm{NPK}+\mathrm{FYM}$ & 12.3 & 8.2 \\
\hline $\mathrm{T}_{6}: 100 \% \mathrm{NPK}+\mathrm{lime}$ & 11.9 & 9.8 \\
\hline $\mathrm{T}_{7}: 100 \% \mathrm{NPK}+\mathrm{Zn}$ & 9.8 & 8.7 \\
\hline $\mathrm{T}_{8}: 100 \% \mathrm{NPK}+\mathrm{HW}$ & 10.8 & 8.9 \\
\hline $\mathrm{T}_{9}: 100 \% \mathrm{NPK}(-\mathrm{S})$ & 9.3 & 9.6 \\
\hline $\mathrm{T}_{10}: 150 \% \mathrm{NPK}$ & 9.4 & - \\
\hline $\mathrm{T}_{11}: 50 \% \mathrm{NPK}$ & 10.3 & 0.81 \\
\hline Initial & 12.1 & 0.58 \\
\hline $\mathrm{CD}(\mathrm{P}=0.05)$ & 0.5 & \\
\hline
\end{tabular}

The continuous use of chemical fertilizers and amendments reduced the CEC values in almost all the treatments except that of $100 \% \mathrm{NPK}+\mathrm{FYM}$ where the initial status of $12.1 \mathrm{c} \mathrm{mol}\left(\mathrm{p}^{+}\right) \mathrm{kg}^{-1}$ was almost maintained. The subsurface layers had lesser values of CEC compared to the surface layer (Table 3). The $\mathrm{pH}$ values in different fertilized treatments in present soils varied from 4.3 to 5.2 excluding control and lime treated plots (Table 1). At such low $\mathrm{pH}$ values, only the permanent charges of the clays and a small portion of the charges of organic colloids hold ions that can be exchanged by cations (Brady, 1990). 
The slight decrease in CEC values of soils in the present study could, therefore, be ascribed to the acidifying effect of chemical fertilizers resulting in reduced $\mathrm{pH}$ values in almost all the treatments and prominently in $100 \% \mathrm{~N}$ treated plots. The comparatively high CEC value in $100 \%$ NPK + FYM treated plots may be attributed to high soil organic carbon content in these plots.

\subsection{Available Nitrogen}

The data presented in Table 4 revealed that available $\mathrm{N}$ content at surface soil layer ranged from $262 \mathrm{~kg}^{-1}$ under control to $351 \mathrm{~kg} \mathrm{ha}^{-1}$ under $100 \%$ NPK + FYM treatment. In general, continuous manuring and cropping for thirty six years showed noticeable decline in available $\mathrm{N}$ content of soils in all the treatments in comparison to initial value. The initial available $\mathrm{N}$ content in soils was $736 \mathrm{~kg} \mathrm{ha}^{-1}$, which declined to $262 \mathrm{~kg} \mathrm{ha}^{-1}$ in the plots receiving zero fertilization after thirty seven years. Application of $100 \% \mathrm{~N}\left(\mathrm{~T}_{2}\right), 100 \% \mathrm{NP}\left(\mathrm{T}_{3}\right)$ and $100 \% \mathrm{NPK}\left(\mathrm{T}_{4}\right)$ resulted in soil $\mathrm{N}$ depletion of 64, 57 and 59 per cent, respectively in comparison to its initial content. Highest increase $(33.9 \%)$ in available $\mathrm{N}$ content over control was recorded with $100 \%$ NPK + FYM followed by $100 \%$ NPK + lime (27.9\%). In case of subsurface soil layer, the content of available N declined with increase in depth in all the treatments. However, the effect of various treatments on available $\mathrm{N}$ content followed the same trend as was observed in surface layer.

TABLE 4

EFFECT OF LONG-TERM USE OF CHEMICAL FERTILIZERS AND AMENDMENTS ON AVAILABLE NITROGEN $\left(\mathrm{kg} \mathrm{ha}^{-1}\right)$

\begin{tabular}{|c|c|c|}
\hline \multirow{2}{*}{ Treatment } & \multicolumn{2}{|c|}{ Soil depth(m) } \\
\cline { 2 - 3 } & $\mathbf{0 - 0 . 1 5}$ & $\mathbf{0 . 1 5 - 0 . 3 0}$ \\
\hline $\mathrm{T}_{1}:$ Control & 262 & 204 \\
\hline $\mathrm{T}_{2}: 100 \% \mathrm{~N}$ & 314 & 288 \\
\hline $\mathrm{T}_{3}: 100 \% \mathrm{NP}$ & 304 & 262 \\
\hline $\mathrm{T}_{4}: 100 \% \mathrm{NPK}$ & 320 & 314 \\
\hline $\mathrm{T}_{5}: 100 \% \mathrm{NPK}+\mathrm{FYM}$ & 351 & 293 \\
\hline $\mathrm{T}_{6}: 100 \% \mathrm{NPK}+$ lime & 335 & 278 \\
\hline $\mathrm{T}_{7}: 100 \% \mathrm{NPK}+\mathrm{Zn}$ & 304 & 293 \\
\hline $\mathrm{T}_{8}: 100 \% \mathrm{NPK}+\mathrm{HW}$ & 330 & 278 \\
\hline $\mathrm{T}_{9}: 100 \% \mathrm{NPK}(-\mathrm{S})$ & 325 & 304 \\
\hline $\mathrm{T}_{10}: 150 \% \mathrm{NPK}$ & 325 & 262 \\
\hline $\mathrm{T}_{11}: 50 \% \mathrm{NPK}$ & 314 & - \\
\hline Initial & 736 & 28.4 \\
\hline $\mathrm{CD}(\mathrm{P}=0.05)$ & 34.4 & \\
\hline
\end{tabular}

The leaching losses of $\mathrm{N}$ under very high rainfall conditions and its application schedule not synchronizing with the crop requirement might be responsible for such a drastic decline in available $\mathrm{N}$ contents. Among different treatments, maximum available N content was recorded under $100 \%$ NPK + FYM treatment after the harvest of wheat crop during 2008-09. The higher content in this treatment may be due to the additional supply of $\mathrm{N}$ through FYM over the years. These results are in consonance with those of Sheeba and Chellamuthu (1999) and Sharma et al. (2002). The lower contents of available $\mathrm{N}$ in untreated plots $\left(\mathrm{T}_{1}\right)$ is result of mining with continuous cropping without fertilization over a period of thirty seven years.

The subsurface soils had comparatively lesser values of available $\mathrm{N}$ than surface layer which might be due to the less accumulation of organic matter in this layer. The decrease in available $\mathrm{N}$ content with increase in soil depth has also been reported by Sheeba and Chellamuthu (1999), Sammy Reddy et al. (2003) and Tabassum et al. (2010).

\subsection{Available Phosphorus}

The data reported in table 5 indicated that the available $\mathrm{P}$ content declined in the plots where application of $\mathrm{P}$ was omitted i.e. control and $100 \% \mathrm{~N}$ treated plots. In general, long-term inclusion of P fertilizers (the treatments involving use of NP and NPK) raised the available soil $\mathrm{P}$ above its initial level of $12 \mathrm{~kg} \mathrm{ha}^{-1}$. The continuous application of graded doses of $\mathrm{P}$ at the rate of 50, 100 and 150 per cent of its recommended level in combination with $\mathrm{N}$ and $\mathrm{K}$ increased the soil available $\mathrm{P}$ content significantly over untreated plots. The available $\mathrm{P}$ content in subsurface soils was less, in general, compared to the surface soils. The treatment effects at both the depths, however, were comparable. 
TABLE 5

EFFECT OF LONG-TERM USE OF CHEMICAL FERTILIZERS AND AMENDMENTS ON AVAILABLE PHOSPHORUS $\left(\mathrm{kg} \mathrm{ha}^{-1}\right)$

\begin{tabular}{|c|r|r|}
\hline \multirow{2}{*}{ Treatment } & \multicolumn{2}{|c|}{ Soil depth(m) } \\
\cline { 2 - 3 } & $\mathbf{0 - 0 . 1 5}$ & $\mathbf{0 . 1 5 - 0 . 3 0}$ \\
\hline $\mathrm{T}_{1}:$ Control & 5.2 & 3.7 \\
\hline $\mathrm{T}_{2}: 100 \% \mathrm{~N}$ & 6.8 & 5.1 \\
\hline $\mathrm{T}_{3}: 100 \% \mathrm{NP}$ & 102.0 & 95.4 \\
\hline $\mathrm{T}_{4}: 100 \% \mathrm{NPK}$ & 120.9 & 113.3 \\
\hline $\mathrm{T}_{5}: 100 \%$ NPK+ FYM & 145.7 & 120.0 \\
\hline $\mathrm{T}_{6}: 100 \%$ NPK+ lime & 117.6 & 108.8 \\
\hline $\mathrm{T}_{7}: 100 \% \mathrm{NPK}+\mathrm{Zn}$ & 108.1 & 79.2 \\
\hline $\mathrm{T}_{8}: 100 \%$ NPK+ HW & 77.4 & 10.0 \\
\hline $\mathrm{T}_{9}: 100 \% \mathrm{NPK}(-\mathrm{S})$ & 109.8 & 151.9 \\
\hline $\mathrm{T}_{10}: 150 \% \mathrm{NPK}$ & 174.0 & 30.6 \\
\hline $\mathrm{T}_{11}: 50 \% \mathrm{NPK}$ & 39.3 & - \\
\hline Initial & 12.0 & 11.1 \\
\hline $\mathrm{CD}(\mathrm{P}=0.05)$ & 9.2 & \\
\hline
\end{tabular}

The substantial build up of available $\mathrm{P}$ with its continuous use in these acidic soils is attributed to low crop recovery of applied P and its high stability in the form of residual P (Sharma and Gupta 1997; Zhang et al. 1995). The increase in available $\mathrm{P}$ might be ascribed to the addition of $\mathrm{P}$ at higher rates in $\mathrm{T}_{10}$ and inactivation of iron, aluminium and hydroxyl aluminium ions, responsible for P fixation by FYM in $\mathrm{T}_{5}$ as has been reported by Verma (2002) in the same experimental set up. Besides, decomposition of organic matter releases appreciable quantity of organic compounds which form a cover on sesquioxides and thus reduces the P fixing capacity of the soil (Sharma et al. 2001). Lime application also markedly increased the available $\mathrm{P}$ status of the soil due to decrease in exchangeable acidity and increase in mineralization of organic phosphates (Kumar and Verma 1997). The low available $\mathrm{P}$ content in $100 \% \mathrm{~N}$ treated plots may be attributed to low pH values of these plots leading to higher $\mathrm{P}$ fixation (Sharma et al. 2002).

\subsection{Available Potassium}

There was an increase in available $\mathrm{K}$ content under all the treatments over control (Table 6). However, the exchangeable $\mathrm{K}$ declined in almost all the treatments in comparison to its status of $194.2 \mathrm{~kg} \mathrm{ha}^{-1}$ at the beginning of the experiment in 1972 except $100 \%$ NPK + FYM treatment. Combining FYM with $100 \%$ NPK, however, maintained the initial K status of soils. Compared to $100 \%$ NPK, application of FYM along with $100 \%$ NPK and $150 \%$ NPK increased available K content by 18.3 and 10.7 per cent, respectively. The exchangeable $\mathrm{K}$ content in the subsurface soils was less in comparison to the surface layers in all the treatments. The treatment wise effect was similar to surface soil layer.

TABLE 6

EFFECT OF LONG-TERM USE OF CHEMICAL FERTILIZERS AND AMENDMENTS ON AVAILABLE POTASSIUM $\left(\mathrm{kg} \mathrm{ha}^{-1}\right)$

\begin{tabular}{|c|c|c|}
\hline \multirow{2}{*}{ Treatment } & \multicolumn{2}{|c|}{ Soil depth(m) } \\
\cline { 2 - 3 } & $\mathbf{0 - 0 . 1 5}$ & $\mathbf{0 . 1 5 - 0 . 3 0}$ \\
\hline $\mathrm{T}_{1}:$ Control & 121.2 & 101.0 \\
\hline $\mathrm{T}_{2}: 100 \% \mathrm{~N}$ & 134.0 & 114.5 \\
\hline $\mathrm{T}_{3}: 100 \% \mathrm{NP}$ & 128.7 & 148.2 \\
\hline $\mathrm{T}_{4}: 100 \% \mathrm{NPK}$ & 167.6 & 176.2 \\
\hline $\mathrm{T}_{5}: 100 \% \mathrm{NPK}+\mathrm{FYM}$ & 198.3 & 156.5 \\
\hline $\mathrm{T}_{6}: 100 \% \mathrm{NPK}+$ lime & 175.1 & 138.1 \\
\hline $\mathrm{T}_{7}: 100 \% \mathrm{NPK}+\mathrm{Zn}$ & 169.9 & 146.5 \\
\hline $\mathrm{T}_{8}: 100 \% \mathrm{NPK}+\mathrm{HW}$ & 165.4 & 149.0 \\
\hline $\mathrm{T}_{9}: 100 \% \mathrm{NPK}(-\mathrm{S})$ & 171.4 & 171.6 \\
\hline $\mathrm{T}_{10}: 150 \% \mathrm{NPK}$ & 185.6 & 127.6 \\
\hline $\mathrm{T}_{11}: 50 \% \mathrm{NPK}$ & 151.2 & - \\
\hline Initial & 194.2 & 5.22 \\
\hline $\mathrm{CD}(\mathrm{P}=0.05)$ & 10.19 & \\
\hline
\end{tabular}


The exclusion of $\mathrm{K}$ in crop nutrition (control, $100 \% \mathrm{~N}$ and $100 \% \mathrm{NP}$ ) has led to the maximum mining of its native pools over the years. These results are in accordance with the findings of Sharma et al. 2002. The high content of available K under $100 \%$ NPK + FYM treatment may be ascribed to additional supply of K through FYM.

\section{CONCLUSIONS}

Significant improvement in the soil properties and availability of nutrients was observed by the addition of FYM in combination with chemical fertilizers in surface as well as subsurface layers. Application of lime periodically during 37 years increased the $\mathrm{pH}$ of soil from its initial value thereby neutralizing the soil acidity. There is a significant increase in soil organic carbon with the continuous application of FYM to maize crop for 37 years. The integrated use of optimal dose of NPK and FYM is helpful in maintaining soil health. Continuous use of recommended levels of N alone through urea (without FYM) has deleterious effect on soil quality. Imbalanced fertilization has proved to be a great threat to the sustainability of our farming systems. Amelioration of soil acidity in Acid Soil Regions (ASR) besides using recommended application rates of $\mathrm{N}, \mathrm{P}$ and $\mathrm{K}$ is a beneficial proposition under situations where availability of organics (FYM) is limited.

\section{ACKNOWLEDGEMENTS}

The authors are highly thankful to Indian Council of Agricultural Research, New Delhi for funding this study in the form of All India Coordinated Research Project on Long-term Fertilizer Experiment. Thanks are also due to the University Authorities for their technical guidance and facilities provided by them to carry out this investigation.

\section{REFERENCES}

[1] Acharya, C.L, Bishnoi, S.K. and Yaduvanshi, H.S. 1988. Effect of long-term application of fertilizers and organic amendments under continuous cropping on soil physical and chemical properties in an Alfisol. Indian Journal of Agricultural Sciences 58 (7): 509-516

[2] Brady NC. 1990. Ecological studies: Analysis and synthesis 33: 39-41

[3] Hue, N.V. 1992. Correcting soil acidity of a highly weathered ultisols with chicken manure and sewage sludge. Commun. in Soil Sci. and Pl. Anal. 23: 241-264

[4] Kumar, S. and Verma, T.S. 1997. Efficiency of lime in improving properties of acid Alfisols of North-West Himalayas. J Ind. Soc. Soil Sci 45 (3 ): 605-607

[5] Magdoff, F., Lanyon, L. and Liebhardt, B. 1997. Nutrient cycling, transformations and flows: Implications for a more sustainable agriculture. Adv. Agron. 60: 1-73

[6] Prasad, J., Shrivastava, N.C. and Mathur, B.S. 1996. Available nutrient status of continuously fertilized and cropped arid soil. J. Ind. Soc. Soil Sci. 44 (1): 171-173.

[7] Sammy Reddy, K, Singh, M, Tripathi AK, Singh, M. and Saha, M.N. 2003. Changes in amount of organic and inorganic fractions of nitrogen in an Eutrochrept soil after long-term cropping with different fertilizer and organic manure inputs. J. Pl. Nutr. Soil Sci. 166 : $232-238$

[8] Sharma, M.P., Bali, S.V. and Gupta, D.K. 2001. Soil fertility and productivity of rice (Oryza sativa)-wheat (Triticum aestivum) cropping system in an inceptisol as influenced by integrated nutrient management. Ind. J. Agric. Sci. 71 (2): 82-86

[9] Sharma, P.K. and Gupta, J.P. 1997. Studies on phosphorus use efficiency as influenced by P, lime and FYM in wheat in an acid Alfisol of Himachal Pradesh. Fert. News 32 (2): 37-40

[10] Sharma, S.P, Subehia, S.K. and Sharma, P.K. 2002. Long term effects of chemical fertilizers on soil quality, crop productivity and sustainability. Research Bulletin CSK Himachal Pradesh Krishi Vishvavidyalaya p 33

[11] Sheeba, S. and Chellamuthu, S. 1999. Long term influence of organic and inorganic fertilization on the macronutrient status of inceptisols. J Ind. Soc. Soil Sci 47 (4): 803-804

[12] Subba Rao, A. and Srivastava, S. 1998. Role of plant nutrients in increasing crop productivity. Fert. News 33 (4): 65-75

[13] Tabassum Shahina, Sammy Reddy, K, Vaishya, U.K, Singh Muneshwar and Biswas, A.K. 2010. Changes in organic and inorganic forms of nitrogen in a Typic Haplustert under Soybean - Wheat system due to conjoint use of inorganic fertilizers and organic manures. J Ind. Soc. Soil Sci 58 (1): 76-85

[14] Verma, S. 2002. Studies on long term effects of chemical fertilizers and amendments on phosphorus dynamics and its budgeting in wet temperate zone soils of Western Himalayas. Msc. Thesis, Department of Soil Science, CSK Himachal Pradesh Krishi Vishvavidyalaya, Palampur, India

[15] Zhang, T.Q, Mackenzie, A.F. and Liang, B.C. 1995. Long-term changes in Mehlich-3 extractable P and K in a sandy loam soil under continuous corn (Zea mays L.). Can. J. of Soil Sci.75 (3): 361-367. 